\title{
Feeding Behavior, Body Weight and Growth Rate during Post-Deprivation Period in Rats
}

\author{
Antonio López-Espinoza, Alma Gabriela Martínez Moreno, \\ Virginia Gabriela Aguilera Cervantes, Elia Valdés Miramontes, \\ Luis Alfonso Mojica Contreras, Monica Navarro-Meza, Claudia Patricia Beltrán-Miranda, \\ Ana Cristina Espinoza-Gallardo \\ Behavioral Feeding and Nutrition Research Center (CICAN), CUSur, University of Guadalajara, Guadalajara, \\ México \\ Email: antonio.lopez@cusur.udg.mx
}

Received 23 September 2015; accepted 27 October 2015; published 30 October 2015

Copyright (C) 2015 by authors and Scientific Research Publishing Inc.

This work is licensed under the Creative Commons Attribution International License (CC BY). http://creativecommons.org/licenses/by/4.0/

(c) (i) Open Access

\begin{abstract}
Deprivation is an environmental experience that organisms are continually exposed to. However, few studies analyze deprivation effects on the consumption pattern during the post-deprivation period systematically. The aim of this study was to evaluate the deprivation effect on feeding pattern, growth rate and body weight during post-deprivation. Sixteen albino rats (3 months old at the beginning of the experiment) were exposed to 72-hour total food deprivation every 15 days. Food and water were freely available during non-deprivation periods. Rats completed three cycles comprised by a free access period followed by food deprivation. Once deprivation was removed, food and water consumption increased and then decreased, while body weight was recovered. Growth rate increased after every deprivation period and reached similar levels to those presented by the control group. Depriving rats from one commodity (i.e., food) cause them to restrain their consumption of the other freely available commodity (i.e., water). Results confirm that food deprivation modifies growth rate, water and food consumption. Additionally, during post-deprivation period, differences between males and females were not registered.
\end{abstract}

\section{Keywords}

Body Weight, Food Intake, Water Intake, Post-Deprivation Period, Growth Rate

\section{Introduction}

When an organism is exposed to a water or food deprivation period, behavioral changes occur, affecting feeding How to cite this paper: López-Espinoza, A., Moreno, A.G.M., Cervantes, V.G.A., Miramontes, E.V., Contreras, L.A.M., Navarro-Meza, M., Beltrán-Miranda, C.P. and Espinoza-Gallardo, A.C. (2015) Feeding Behavior, Body Weight and Growth Rate during Post-Deprivation Period in Rats. Food and Nutrition Sciences, 6, 1307-1315. 
patterns and body weight. Some of these changes include: a) feeding behavior adaptation to food availability periods [1] [2]; b) increase in the consumption rate during the food availability period [3]; c) general activity increase on experimental subjects [4]; d) the production of stable states in the organism subjected to experimentation, which results from different deprivation conditions and levels [5]; and of course, e) body weight loss. Deprivation of water or food has been an experimental tool widely used in several sciences (i.e., Experimental Psychology and Physiology) [6] [7]. Additionally, diverse studies have reported the effects that take place on feeding pattern during post-deprivation period [2] [8]-[10]. Hebb [11] observed that during the first free access day after a deprivation period, food consumption was smaller compared with that registered before deprivation. Collier, Hirsch and Kanareck [12] reported that during post-deprivation period, food consumption initiated with a sudden increase, maintaining until it gradually reached a stable maximum. Body weight increased as a result of food consumption changes, descending later until it finally returned to levels similar to those registered previous deprivation.

Siegel [10], on the other hand, used different deprivation programs to characterize the rat consumption pattern. He observed that when a four-hour matutinal deprivation period ended, they ate as usual. Nevertheless, the same method applied nocturnally caused animals to increase their consumption after deprivation. These animals consumptions were compared with those presented by control subjects kept under free access throughout of experiment. Siegel [10] concluded that the time interval used in deprivation programs was related with food consumption when restriction finalized. Corwin and Buda-Levin [13] mentioned that deprivation periods exposure was an important element in the binge-eating type behavior development. They reported that repeated cycles of restriction/refeeding were a suitable model to study this type of behavior, especially when rats were used, because intake increase was the standard effect after deprivation was applied. Barbano and Cador [14] evaluated multiple feeding behavior components as function of deprivation level as well as palatability of the available food; their analysis indicated that anticipatory activity was mainly regulated by food restriction, whereas consumption and running for food were under the influence of homeostatic and food incentive mechanisms.

With this previous evidence, the role of deprivation on eating behavior is undeniable, especially over food consumption. Nevertheless, a great percentage of studies have only focused on analyzing food consumption changes while applying different deprivation programs. During the post-deprivation or refeeding period, other modifications that we consider necessary to evaluate, like changes in growth rate, water consumption or behavioral differences between males and females occur. This last variable is of special interest since a great percentage of studies only use male rats. There are few studies that report deprivation effects on post-deprivation feeding pattern in females [15]-[17]; and in female and male reports, it is only possible to find experiments that evaluate feeding preferences [18]-[24] or diet effects on feeding pattern [25]-[28].

This experiment purpose was, therefore, to explore food restriction and refeeding cycles effects on subsequent feeding behavior, body weight and growth rate in female and male rats. From evidence, we hypothesized that animals exposed to food deprivation would be more likely to show subsequent disturbances in eating patterns and behavior; specifically binge eating, binge drinking, body weight recovery and growth rate increase. Water and food consumption was registered before, during and after deprivation. Also variations on body weight and growth rate were analyzed. Experimental conditions were designed to evaluate deprivation effects on body weight, food and water intake, growth rate and sexual differences during post-deprivation period.

\section{Methods and Materials}

\subsection{Subject}

Experimental subjects were 16 Winstar strain rats, 8 males (ME1, ME2, ME3, ME4, ME5 ME6, ME7, and M8) and 8 females (HE1, HE2, HE3, HE4, HE5, HE6, HE7, and HE8). Another 16 rats were control subjects (8 males: MC1, MC2, MC3, MC4, MC5, MC6, MC7, and MC8, and 8 females: HC1, HC2, HC3, HC4, HC5, HC6, $\mathrm{HC} 7$, and HC8). At the beginning of the experiment, female rats weighed $279 \pm 14.7 \mathrm{~g}$ average and were 90 days old. Male rats weighed $413.85 \pm 12.65 \mathrm{~g}$ (means $\pm \mathrm{SEM}$ ) and had the same age. Animals were singly housed in standard individual cages in an equipped room $(21 \mathrm{C}+/-2 \mathrm{C})$ under a 12:12 light-dark cycle. All procedures in the present study were performed in accordance to the principles outlined by the Mexican Official Norm (NOM-062-ZOO-1999), Technical Specifications for the Production, Care and Use of Laboratory Animals.

\subsection{Apparatus}

All experimental operations were performed in individual home cages, constructed of Plexiglas $(13 \times 27 \times 38$ 
$\mathrm{cm}$ ), with sawdust on the bottom, which was changed every 3 days. We used a precision electronic scale for body weight and food consumption measurements.

\subsection{Food}

Standard Purina Roden Chow food for laboratory animals was used. Food consumption was registered in grams/ day and water consumption in $\mathrm{ml} / \mathrm{day}$.

\subsection{Procedure}

Rats were divided in two groups, experimental and control, equated by body weight. Experimental group (males $\mathrm{n}=8$, females $\mathrm{n}=8$ ) initiated with a 15 days baseline period to determine body weight, food and water intake. Food was removed the following morning at $9 \mathrm{~h}$ during 72 hours to initiate the first deprivation period. Subjects returned to free access conditions during a 15 days period. This food deprivation-free access cycle was repeated until completing three cycles (periods 1, 2 and 3). The lasted free access period lasted 30 days. Control group (males $\mathrm{n}=8$, females $\mathrm{n}=8$ ) had free access to food and water during all the experiment. Food and water intake, and body weight were measured daily.

\subsection{Data Acquisition and Statistical Methods of Analysis}

Data (food and water intake and body weight) was registered every day at $9 \mathrm{~h}$ in the morning, during 84 days. After data collection, we calculated means \pm and standard error for body weight, food and water consumption, cumulative food intake and growth rate for both groups. Growth rate $(\mathrm{Gr})$ was obtained as follows:

$$
G r=(f w-i w) / t
$$

where $f w$ represents the final weight and $i w$ initial weight in a free access period; and $t$ represents this period duration (in this case it was of 15 days). The last post-deprivation period was subdivided in two; from this subdivision periods 4 and 5 were obtained. A parametric contrast method, the Student's $t$ test was used to compare each group averages; since two independent groups of individuals were observed regarding a numerical variable under the assumptions of normality and equal variance. The graphics were created with Sigma Plot ${ }^{\circledR}$.

\section{Results}

\subsection{Body Weight}

During the first 15 days there was no significant difference in the animals baseline weights (Figure 1). During the $72 \mathrm{~h}$ of the first food deprivation period, weight registered in experimental males was $375 \pm 12 \mathrm{~g}$ (means \pm SEM) versus control males $431.3 \pm 13.2 \mathrm{~g}$ (means \pm SEM) and experimental females $245 \pm 13.2 \mathrm{~g}$ (means \pm SEM) versus control females $286.1 \pm 13.7 \mathrm{~g}$ (means \pm SEM). Statistical difference was significant $\mathrm{p}<0.01$. In the post-deprivation period, weight loss was recovered. It took experimental males 15 days to reduce body weight difference to $443 \pm 13.1 \mathrm{~g}$ (means \pm SEM) compared with control males $454.8 \pm 11 \mathrm{~g}$ (means \pm SEM) $\mathrm{P}$ $<0.05$, while it took experimental females 5 days to recover weight and show no significant difference with control females. Such body weight loss and recovery repeated itself in the following deprivation-post-deprivation cycles. Experimental and control subjects did not show significant differences in body weight at the end of the experiment.

\subsection{Total Food Intake}

Within the first 15 days total food intake was not statistical different (Figure 1). During deprivation periods, food consumption was $0 \mathrm{~g}$ for experimental subjects. During the first day of post-deprivation period, total food intake was significantly larger than during subsequent days (binge eating). The first total food intake was $37.3 \pm$ $0.8 \mathrm{~g}$ (means $\pm \mathrm{SEM}$ ) for experimental males versus $28.5 \pm 1.1 \mathrm{~g}$ (means $\pm \mathrm{SEM}$ ) for control males and experimental females consumed $26.25 \pm 1 \mathrm{~g}$ (means \pm SEM) versus control females $18.7 \pm 0.5 \mathrm{~g}$ (means $\pm \mathrm{SEM}) \mathrm{p}<$ 0.01 . Only experimental females maintained this increase on the total food consumption during 4 or 5 days, returning later to control subjects consumption levels. This food consumption increase repeated itself after every deprivation period. 
M A L E S
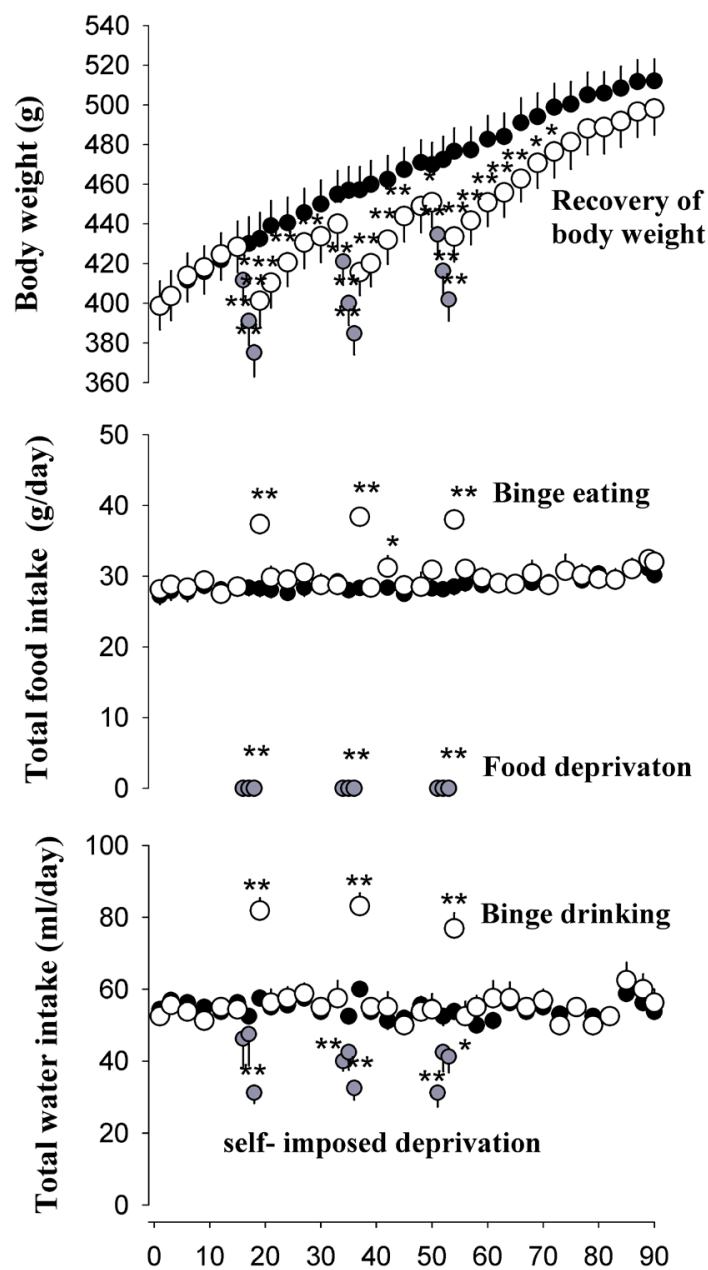

F E M A L E S
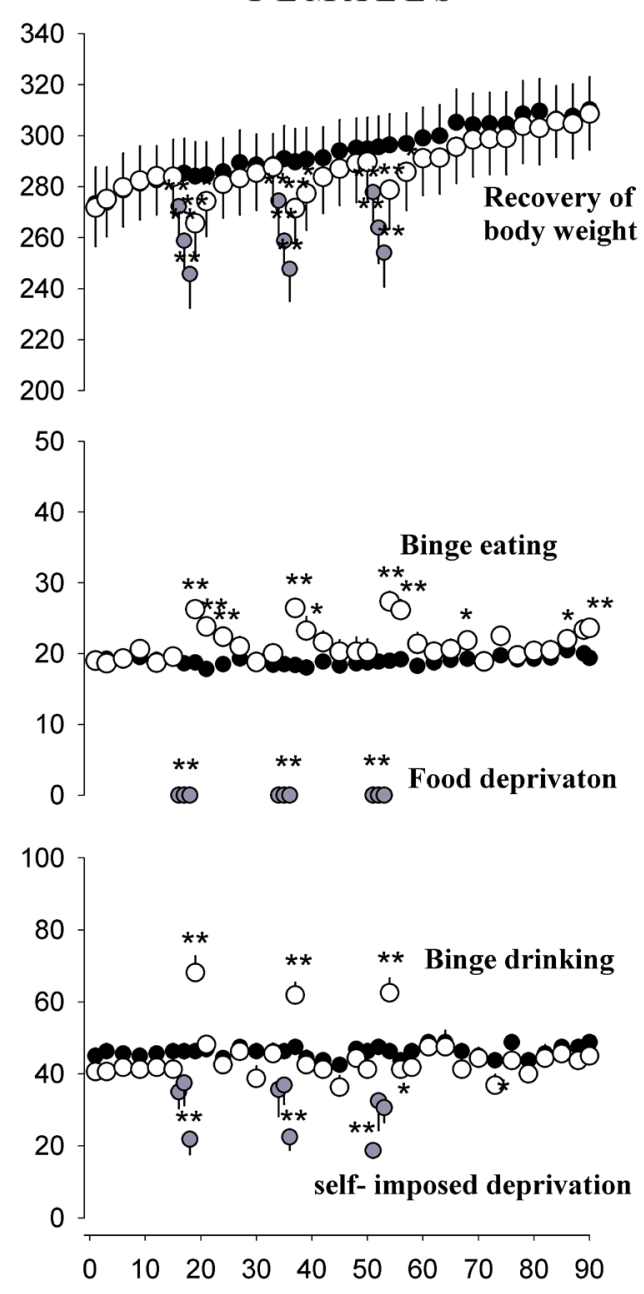

D A Y S

Figure 1. Body weight, total food intake and total water intake of males and females, during 84 days, white circles represents experimental subjects during free access, gray circles represents experimental subjects during deprivation period and black circles represent control subjects. Values are means \pm SEM. ${ }^{*} \mathrm{p}<0.05,{ }^{* *} \mathrm{p}<$ 0.01 , significance of difference from control subjects. The white and black circles represents the average of two or three data.

\subsection{Total Water Intake}

Similarly to total food consumption, total water consumption during the baseline did not have a sadistically significant difference (Figure 1). During the food deprivation period, a water consumption reduction occurred (self-imposed deprivation). Water intake was $37.5 \pm 5.2 \mathrm{ml}$ (means $\pm \mathrm{SEM}$ ) for experimental males versus 56.2 $\pm 1.8 \mathrm{ml}$ (means $\pm \mathrm{SEM}$ ) for control males, and experimental females drank $22.5 \pm 3.6 \mathrm{ml}$ (means $\pm \mathrm{SEM}$ ) versus control females $45 \pm 1.8 \mathrm{ml}$ (means $\pm \mathrm{SEM}$ ) $\mathrm{p}<0.01$. Nevertheless, when returned free access, experimental rats showed a significant increase in water consumption (binge drinking) compared to control subjects. Water intake was $81.8 \pm 3.5 \mathrm{ml}$ (means $\pm \mathrm{SEM}$ ) for experimental males versus $57.5 \pm 1.6 \mathrm{ml}$ (means $\pm \mathrm{SEM}$ ) for control males, and $68.1 \pm 4.6 \mathrm{ml}$ (means $\pm \mathrm{SEM}$ ) for experimental females versus $46.2 \pm 1.8 \mathrm{ml}$ (means $\pm \mathrm{SEM}$ ) $\mathrm{p}<$ 0.01 for control females. This result repeated itself in all post-deprivation periods.

\subsection{Cumulative Food Intake}

Throughout the experiment, cumulative food consumption did not present significant differences. 


\subsection{Growth Rate}

During the first free access period, there was not statistically significant difference (Figure 2). The first free access post-deprivation period, presented statistically significant difference. Growth rate was $2.5 \pm 0.2 \mathrm{~g} /$ day (means $\pm \mathrm{SEM}$ ) for experimental males versus $1.3 \pm 0.12 \mathrm{~g} /$ day (means $\pm \mathrm{SEM}$ ) for control males; for experimental females $1.5 \pm 0.6 \mathrm{~g} /$ day (means $\pm \mathrm{SEM}$ ) versus $0.6 \pm 0.06 \mathrm{~g} /$ day (means $\pm \mathrm{SEM}$ ) for control females, $\mathrm{p}<$ 0.01 . Statistical difference tended to get reduced; at the end of the experiment growth rate was $.22 \pm 0.11 \mathrm{~g} /$ day (means \pm SEM) on experimental males versus $0.69 \pm 0.13 \mathrm{~g}$ /day (means \pm SEM) for control males, $\mathrm{p}<0.05$. Growth rate in experimental females versus control females was not significantly different during the last free access period.

\subsection{Relation between Body Weight Recovery and Growth Rate}

The relationship between body weight recovery and growth rate was an interesting finding. When body weight decreased during deprivation periods and recovering on the $2 \mathrm{nd}$, 3rd, and 4th post-deprivation periods (free access) growth rate increased. However, during the 5th post-deprivation period, body weight recovery was related to a growth rate decrease (Table 1). This relation was clearer during the last 15-day period, in which statistical difference disappeared in females and significantly diminished in males.

M A L E S

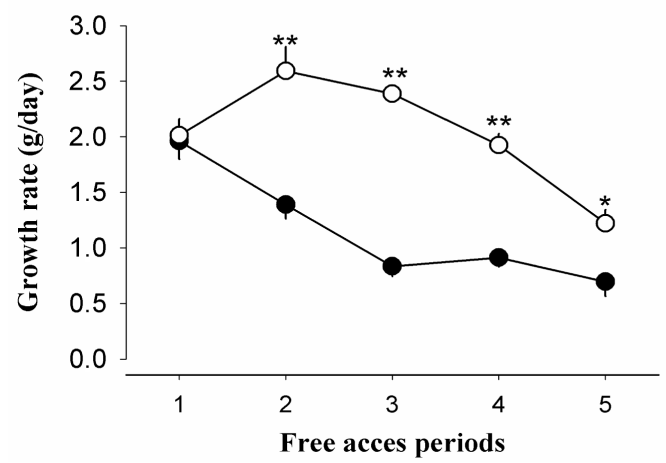

F E M A L E S

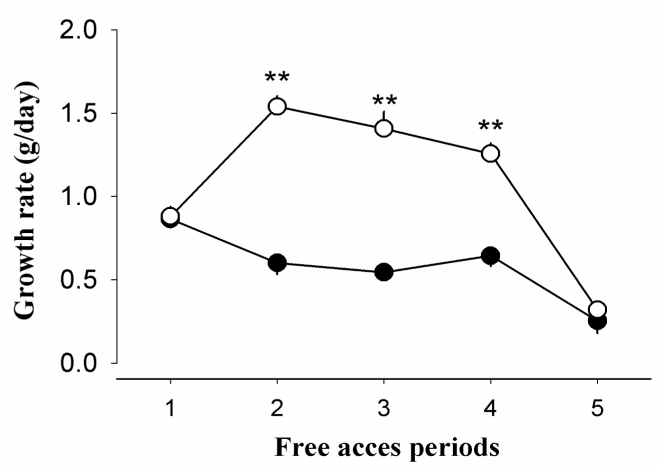

Figure 2. Graphs represent the growth rate (g/day) during free access periods. The white circles represent experimental subjects and black circles control subjects. Values are means \pm SEM. ${ }^{*} \mathrm{p}<0.05,{ }^{* *} \mathrm{p}<0.01$, significance of difference from control subjects.

Table 1. Comparison between body weight recovery and growth rate.

\begin{tabular}{|c|c|c|c|c|c|c|c|c|c|}
\hline \multicolumn{2}{|c|}{ Free access Periods } & \multirow[t]{2}{*}{1 Baseline } & \multicolumn{2}{|c|}{2 Post-deprivation } & \multicolumn{2}{|c|}{3 Post-deprivation } & \multicolumn{2}{|c|}{4 Post-deprivation } & 5 Post-deprivation \\
\hline Male & & & & $\mathbf{p}$ & & $\mathbf{p}$ & & $\mathbf{p}$ & $\mathbf{p}$ \\
\hline Control & Weight & $413.2 \pm 13.1 \mathrm{~g}$ & $443 \pm 12.4 \mathrm{~g}$ & & $464.2 \pm 11.4 \mathrm{~g}$ & & $484.3 \pm 11.9 \mathrm{~g}$ & & $506.1 \pm 11.1 \mathrm{~g}$ \\
\hline Experimental & Weight & $414.5 \pm 12.6 \mathrm{~g}$ & $\downarrow 422 \pm 12.6 \mathrm{~g}$ & $<0.01$ & $\downarrow 435 \pm 12.3 \mathrm{~g}$ & $<0.01$ & $\downarrow 452 \pm 12.2 \mathrm{~g}$ & $<0.01$ & $\uparrow 488 \pm 13.1 \mathrm{~g}$ \\
\hline Experimental & Growth rate & $2 \pm 0.14 \mathrm{~g}$ & $\uparrow 2.5 \pm 0.2 \mathrm{~g}$ & $<0.01$ & $\uparrow 2.3 \pm 0.07 \mathrm{~g}$ & $<0.01$ & $\uparrow 1.9 \pm 0.10 \mathrm{~g}$ & $<0.01$ & $\downarrow 1.2 \pm 0.11 \mathrm{~g}<\mathbf{0 . 0 5}$ \\
\hline Control & Growth rate & $1.96 \pm 0.16 \mathrm{~g}$ & $1.3 \pm 0.1 \mathrm{~g}$ & & $0.83 \pm 0.09 \mathrm{~g}$ & & $0.91 \pm 0.08 \mathrm{~g}$ & & $0.69 \pm 0.1 \mathrm{~g}$ \\
\hline \multicolumn{10}{|l|}{ Female } \\
\hline Control & Weight & $279 \pm 14.1 \mathrm{~g}$ & $286.7 \pm 12.8 \mathrm{~g}$ & & $292.5 \pm 12.3 \mathrm{~g}$ & & $303.3 \pm 12.2 \mathrm{~g}$ & & $307.3 \pm 12.7 \mathrm{~g}$ \\
\hline Experimental & Weight & $279.4 \pm 15.1 \mathrm{~g}$ & $\downarrow 279 \pm 14.1 \mathrm{~g}$ & $<0.01$ & $\downarrow 283 \pm 14.4 \mathrm{~g}$ & $<0.01$ & $\downarrow 290 \pm 14.5 \mathrm{~g}$ & $<0.01$ & $\uparrow 303 \pm 14.1 \mathrm{~g}$ \\
\hline Experimental & Growth rate & $0.88 \pm 0.05 \mathrm{~g}$ & $\uparrow 1.5 \pm 0.06 \mathrm{~g}$ & $<0.01$ & $\uparrow 1.4 \pm 0.10 \mathrm{~g}$ & $<0.01$ & $\uparrow 1.2 \pm 0.06 \mathrm{~g}$ & $<0.01$ & $0.3 \pm 0.04 \mathrm{~g}$ \\
\hline Control & Growth rate & $0.86 \pm 0.05 \mathrm{~g}$ & $0.6 \pm 0.06 \mathrm{~g}$ & & $0.5 \pm 0.04 \mathrm{~g}$ & & $0.6 \pm 0.06 \mathrm{~g}$ & & $0.2 \pm 0.07 \mathrm{~g}$ \\
\hline
\end{tabular}

Results show an analysis of the data on post-deprivation periods. Means \pm SEM of body weight and growth rate of experimental versus control groups was compared. Arrows indicate the relation between body weight and growth rate of experimental subjects. 


\section{Discussion}

Findings clearly show that food deprivation causes important changes during post-deprivation period in males as much as in females. Post deprivation periods changes were, body weight recovery, binge eating, binge drinking related to self-imposed deprivation, and a growth rate increase. Post-deprivation changes were observed in both inter- and intra-subjects statistical analyses.

\subsection{Body Weight Recovery by Growth Rate Increase}

Previous weight regulation and compensatory growth studies have used models which expose animals to food deprivation programs. These studies outcomes have not taken post-deprivation growth rate increase into consideration [29]-[33]. In contrast, this experiment examined weight recovery associated with growth rate increase. Data indicated that growth rate increase was inversely proportional to body weight recovery during post-deprivation periods. Statistical analyses indicated that the 15 days post-deprivation periods were sufficient to detect differences between groups. It is important to indicate that during the last 15 days of the experiment, statistical differences between groups disappeared. These data suggests that deprivation effect on post-deprivation periods has a limited duration, and confirm similar observations that have led some investigators to postulate that growth rate works as a compensatory mechanism, that regulates weight changes to maintain body weight [29] [34] [35]. Table 1 shows post-deprivation period growth rate data. Such information allows to conclude that weight recovery might be regulated by growth rate and does not exclusively depend on food consumption. Also the organism's physical activity during the post-deprivation periods is a factor that can possibly modify growth rate; however, other experiments are necessary to explore which factors influence growth rate.

\subsection{Binge Eating}

The present experiment results support the findings of previous studies showing that deprivation increases food intake during post-deprivation periods [36]-[39]. Several studies have considered that food restriction and binge eating co-occur [36] [37] [40]. Our results demonstrated that this relation appeared during all deprivation-postdeprivation cycles (Figure 1). Statistical analyses indicated that difference in food consumption between experimental and control groups was statistically significant $(p<0.01)$ during the first 2 days in males and the first 4 - 6 days in females during post-deprivation periods. These data suggest that binge eating might be a regulatory behavior that appears only during the first days of the post-deprivation period. This is supported by total food intake analyses. No statistical differences in accumulative food intake between experimental and control group was observed, suggesting that the general food consumption pattern was not modified. This result supports the alternative explanation of binge eating as a regulatory behavior.

\subsection{Binge Drinking by Self-Imposed Deprivation}

Polydipsia is a stereotyped pattern of drinking that can be caused by a variety of pathological or experimental factors [41] [42]. In order to understand the water consumption increase causes, several types of animal polydipsia models have been developed: a) traumatic (e.g., supraoptic nucleus lesions in the hypothalamus) [43]; b) pathological (e.g., diabetes) [44] [45]; c) schedule-induced polydipsia, [46] [47]; and d) drugs-induced polydipsia [48] [49]. The basic characteristic of polydipsia is its temporary persistence maintained by: programs, drugs or diseases. Our results show a different type of increase in water consumption. The term "binge drinking" is used to refer to post-deprivation water over consumption, due to its similarities with binge eating. Statistical analyses indicated that water consumption between experimental and control groups was statistically significant $(\mathrm{p}<0.01)$ only during the first day of post-deprivation period (binge drinking) in males and females. This data suggests that self-imposed water deprivation, food deprivation and binge drinking co-occur, as with binge eating (Figure 1).

\subsection{Differences between Females and Males}

These results suggest that, the deprivation program had the same effect in females and males, that is to say, no differences were observed in the body weight recovery, binge eating or binge drinking. Sefcikova and Mozes [15] reported that adult female rats showed overfeeding episodes when they were exposed to nutrients restriction 
periods previously. They concluded that a relation between the experience with restrictive diet and food consumption changes include overfeeding. On the other hand, Kennedy [50] indicated that females and males rats show differences in their body weight regulation, because males are more responsive to feeding signals than females. Nevertheless, results obtained on the present experiment did not show differences in body weight recovery between females and males in the post-deprivation periods. The exposition to other types of foods, could possibly determine some type of differences in body weight and food consumption between males and females. For example, it has been observed that female rats consume more sweetened solutions than males, especially when those contain calories [51] [52]. Apparently, sex can represent an important variable on eating behavior study.

\subsection{Limitations}

Binge eating and binge drinking inadequate operational characterization was a limitation for this study. Scientific evidence has identified these two types of behavior, from an increase of food and water consumption compared to baseline [13] [38] [39] [53]. However, exactly determining the increment amount or percentage that characterizes this type of behavior is still a pending task. Another limitation was the 24 hour consumption measurement, because to identify the time and conditions under which binge eating and binge drinking are presented, is necessary to perform a day long analysis.

\section{Conclusion}

It seems reasonable to conclude that food deprivation modifies multiple factors during the post-deprivation period. These changes are called post-deprivation effects. Binge eating and binge drinking are related to deprivation and its nature seems to be regulatory due to the fact that it disappears when deprivation is retired. Body weight recovery is related to growth rate. Further work is necessary to clarify which factors influence growth rate, and to explore deprivation intensity variations and their effects on binge eating, binge drinking and selfimposed deprivation.

\section{Acknowledgements}

The research is financed by CONACYT project-CB 156821 .

\section{References}

[1] Lawrence, D.H. and Mason, W.A. (1955) Intake and Weight Adjustments in Rats Changes in Feeding Schedule. The Journal of Comparative and Physiological Psychology, 48, 43-45. http://dx.doi.org/10.1037/h0047096

[2] Reid, L.S. and Finger, F.W. (1955) The Rats Adjustment to 23-Hour Food-Deprivation Cycles. The Journal of Comparative and Physiological Psychology, 48, 110-113. http://dx.doi.org/10.1037/h0042051

[3] Bolles, R.C. (1973) Teoría de la motivación. Trillas, México.

[4] Horenstein, B.R. (1951) Performance of Conditioned Responses as a Function of Strength of Hunger Drive. The Journal of Comparative and Physiological Psychology, 43, 210-224. http://dx.doi.org/10.1037/h0059362

[5] Clark, F.C. (1958) The Effect of Deprivation and Frequency of Reinforcement on Variable-Interval Responding. Journal of the Experimental Analysis of Behavior, 1, 221-227. http://dx.doi.org/10.1901/jeab.1958.1-221

[6] Pavlov, I.P. (1927) Conditioned Reflex and Psychiatry. International Publishers, New York.

[7] Skinner, B.F. (1932) On the Rate of Formation of a Conditioned Reflex. Journal General Psychology, 7, 274-286. http://dx.doi.org/10.1080/00221309.1932.9918467

[8] Fay, J.C., Miller, J.D. and Harlow, H.F. (1953) Incentive Size, Food Deprivation and Food Preference. Journal of Comparative and Physiological Psychology, 46, 13-15. http://dx.doi.org/10.1037/h0056080

[9] Lowe, M.R. (1993) The Effects of Dieting on Eating Behavior: A Three-Factor Model. Psychological Bulletin, 114, 100-121. http://dx.doi.org/10.1037/0033-2909.114.1.100

[10] Siegel, P.S. (1961) Food Intake in the Rat in Relation to the Dark-Light Cycle. Journal of Comparative and Physiological Psychology, 54, 294-301. http://dx.doi.org/10.1037/h0044787

[11] Hebb, D.O. (1949) The Organization of Behavior: A Neuropsychological Theory. Wiley, New York.

[12] Collier, G., Hirsch, E. and Kanarek, R. (1983) La operante vista de nuevo. In: Honig, W.K. and Staddon, J.E.R., Eds., 
Manual de conducta operante, Trillas, México, 47-78.

[13] Corwin, R.L. and Buda-Levin, A. (2004) Behavioral Models of Binge-Type Eating. Physiology \& Behavior, 83, 123130. http://dx.doi.org/10.1016/i.physbeh.2004.04.036

[14] Barbano, M.F. and Cador, M. (2005) Various Aspects of Feeding Behavior Can Be Partially Dissociated in the Rat by the Incentive Properties of Food and the Physiological State. Behavioral Neuroscience, 119, 1244-1253. http://dx.doi.org/10.1037/0735-7044.119.5.1244

[15] Sefcikova, Z. and Mozes, S. (2002) Effect of Early Nutritional Experience on the Feeding Behaviour of Adult Female Rats. Veterinarni Medicina, 47, 315-322.

[16] Díaz, F., García, K., Navarro, L., Franco, K., Valdés, E. and Beltrán-Miranda, C.P. (2010) Effect of Deprivation on Food Intake in Female Rats. Revista Mexicana de Análisis de la Conducta, 36, 169-183.

[17] Zeigler, H.P., Green, H.L. and Lehrer, R. (1971) Patterns of Feeding Behavior in the Pigeon. Journal of Comparative and Physiological Psychology, 76, 468-477. http://dx.doi.org/10.1037/h0031395

[18] Mook, D.G. (1974) Saccharin Preference in the Rat: Some Unpalatable Findings. Psychological Review, 81, $475-490$. http://dx.doi.org/10.1037/h0037238

[19] Valenstein, E.S., Cox, V.C. and Kakolewski, J.W. (1970) Reexamination of the Role of the Hypothalamus in Motivated Behavior. Psychological Review, 77, 16-31. http://dx.doi.org/10.1037/h0028581

[20] Bashkatova, V., Sudakov, S., Nazarova, G. and Alexeeva, E. (2014) The Action of Chronic Nicotine on the Effects of Ethanol on Anxiety, Locomotion and Metabolism and the Feeding and Drinking Behaviors of Rats. Pharmacology \& Pharmacy, 5, 1077-1084. http://dx.doi.org/10.4236/pp.2014.511117

[21] Barnett, S.A. and Spence, M.M. (1953) Experiments on the Food Preferences of Wild Rats (Rattus norvegicus Berkenhout). Journal of Hygiene, 51, 16-34. http://dx.doi.org/10.1017/S002217240001545X

[22] Suliman, S.M., Shumake, S.A. and Jackson, W.B. (1984) Food Preference in the Nile Rat Arvicanthis niloticus. Tropical Pest Management, 30, 151-158. http://dx.doi.org/10.1080/09670878409370869

[23] Galef, B.G. (2003) Social Learning of Food Preferences in Rodents: Rapid Appetitive Learning. Current Protocols in Neuroscience, 21, 8.5D.1-8.5D.8. http://dx.doi.org/10.1002/0471142301.ns0805ds21

[24] Ackroff, K. and Sclafani, A. (2004) Fructose-Conditioned Flavor Preferences in Male and Female Rats: Effects of Sweet Taste and Sugar Concentration. Appetite, 42, 287-297. http://dx.doi.org/10.1016/j.appet.2008.05.059

[25] Marounek, M., Volek, Z., Skrivanová, E. and Czauderna, M. (2012) Gender-Based Differences in the Effect of Dietary Cholesterol in Rats. Central European Journal of Biology, 7, 980-986. http://dx.doi.org/10.2478/s11535-012-0091-7

[26] Jenkins, T.C. and Hershberger, T.V. (1978) Effect of Diet, Body Type and Sex on Voluntary Intake, Energy Balance and Body Composition of Zucker Rats. Journal of Nutrition, 108, 124-136.

[27] Radcliffe, J.D. and Webster, A.J. (1976) Regulation of Food Intake during Growth in Fatty and Lean Female Zucker Rats Given Diets of Different Protein Content. British Journal of Nutrition, 36, 457-469. http://dx.doi.org/10.1079/BJN19760100

[28] Martínez, A.G., López-Espinoza, A., de León, I., Solano, L. and Hernández-Leonardo, F. (2014) Conditioned Taste Aversion Diminishes Sugar Intake. Food and Nutrition Sciences, 5, 997-1004. http://dx.doi.org/10.4236/fns.2014.511110

[29] Zeigler, H.P., Green, H.L. and Siegel, H. (1972) Food and Water Intake and Weight Regulation in the Pigeon. Physiology \& Behavior, 8, 127-134. http://dx.doi.org/10.1016/0031-9384(72)90139-4

[30] Ali, M. and Wotoon, R.J. (2000) Pattern of Hyperphagia in Immature Three-Spined Sticklebacks after Short-Term Food Deprivation. Journal of Fish Biology, 56, 648-653. http://dx.doi.org/10.1111/j.1095-8649.2000.tb00762.X

[31] Quian, X., Cui, Y., Xiong, B. and Yang, Y. (2000) Compensatory Growth, Feed Utilization and Activity in Gibel Carp, Following Feed Deprivation. Journal of Fish Biology, 56, 228-232. http://dx.doi.org/10.1111/j.1095-8649.2000.tb02101.X

[32] Zhu, X., Cui, Y., Ali, M. and Wooton, R.J. (2001) Comparison of Compensatory Growth Responses of Juvenile ThreeSpined Stickleback and Minnow Following Similar Food Deprivation Protocols. Journal of Fish Biology, 58, 11491165. http://dx.doi.org/10.1111/j.1095-8649.2001.tb00562.x

[33] Tian, X. and Qin, J.G. (2003) A Single Phase of Food Deprivation Provoked Compensatory Growth in Barramundi Lates calcarifer. Aquaculture, 224, 169-179. http://dx.doi.org/10.1016/s0044-8486(03)00224-2

[34] Levin, B.E. and Dunn-Meynell, A.A. (2000) Defense of Body Weight against Chronic Caloric Restriction in ObesityProne and -Resistant Rats. American Journal of Physiology. Regulatory, Integrative and Comparative Physiology, 278, R231-R237.

[35] Levin, B.E. and Dunn-Meynell, A.A. (2002) Defense of Body Weight Depends on Dietary Composition and Palatabil- 
ity in Rats with Diet-Induced Obesity. American Journal of Physiology. Regulatory, Integrative and Comparative Physiology, 282, R46-R54.

[36] Franklin, J.S., Schiele, B.C., Brozek, J. and Keys, A. (1948) Observations on Human Behavior in Experimental Semistarvation and Rehabilitation. Journal of Clinical Psychology, 4, 28-45. http://dx.doi.org/10.1002/1097-4679(194801)4:1<28::AID-JCLP2270040103>3.0.CO;2-F

[37] Polivy, J. and Herman, P. (1985) Dieting and Binging: A Causal Analysis. American Psychologist, 40, $193-201$. http://dx.doi.org/10.1037/0003-066X.40.2.193

[38] Corwin, R.L. (2000) Biological and Behavioral Consequences of Food Restriction. Appetite, 34, 112. http://dx.doi.org/10.1006/appe.1999.0288

[39] López-Espinoza, A. and Martínez, H. (2004) Cambios del patrón alimentario como efecto de la privación de agua o alimento en ratas en crecimiento. International Journal of Psychology and Psychological Therapy, 4, 93-104.

[40] Lachaussée, J.L., Kissileff, H.R., Walsh, B.T. and Hadigan, C.M. (1993) The Single-Item Meal as a Measure of BingeEating Behavior in Patients with Bulimia Nervosa. Physiology \& Behavior, 51, 593-600. http://dx.doi.org/10.1016/0031-9384(92)90185-5

[41] Ramsay, D.J. and Booth, D.A. (1991) Thirst. Physiological and Psychological Aspects. Springer, London. http://dx.doi.org/10.1007/978-1-4471-1817-6

[42] Todd, J.T., Cunningham, L.A., Janes, A.A., Mendelson, J. and Morris, E.K. (1997) The Generation and Maintenance of Schedule-Induced Polydipsia in Normal Male Rats without Weight Reduction. Physiology \& Behavior, 62, 13851390. http://dx.doi.org/10.1016/S0031-9384(97)00367-3

[43] Ralph, C.L. (1960) Polydipsia in the Hen Following Lesions in the Supraoptic Hypothalamus. The American Journal of Physiology, 198, 528-530.

[44] Saito, T., Ishikawa, S., Ito, T., Oda, H., Ando, F., Higashiyama, M., Nagasaka, S., Hieda, M. and Saito, T. (2005) Urinary Excretion of Aquaporin-2 Water Channel Differentiates Psychogenic Polydipsia from Central Diabetes Insipidus. The Journal of Clinical Endocrinology \& Metabolism, 84, 2235-2237. http://dx.doi.org/10.1210/jcem.84.6.5715

[45] Thorkildsen, C., Neve, S., Larsen, B.D., Meier, E. and Petersen, J.S. (2003) Glucagon-Like Peptide 1 Receptor Agonist ZP10A Increases Insulin mRNA Expression and Prevents Diabetic Progression in $\mathrm{db} / \mathrm{db}$ Mice. The Journal of Pharmacology and Experimental Therapeutics, 307, 490-496. http://dx.doi.org/10.1124/jpet.103.051987

[46] Pellón, R. and Blackman, D.E. (1987) Punishment of Schedule-Induced Drinking in Rats by Signaled and Unsignaled Delays in Food Presentation. Journal of the Experimental Analysis of Behavior, 48, 417-434. http://dx.doi.org/10.1901/jeab.1987.48-417

[47] Kirsch, I., Lynn, S.J., Vigorito, M. and Miller, R.R. (2004) The Role of Cognition in Classical and Operant Conditioning. Journal of Clinical Psychology, 60, 369-392. http://dx.doi.org/10.1002/jclp.10251

[48] Tomie, A., Sparta, D.R., Silberman, Y., Interlandi, J., Mynko, A., Patterson-Buckendahl, P. and Pohorecky, L.A. (2002) Pairings of Ethanol Sipper with Food Induces Pavlovian Autoshaping of Ethanol Drinking in Rats: Evidence of Long-Term Retention and Effects of Sipper Duration. Alcohol \& Alcoholism, 37, 547-554. http://dx.doi.org/10.1093/alcalc/37.6.547

[49] Yazar, E., Demir, O., Elmas, M., Bas, A. and Tras, B. (2002) Phenobarbital Effects on Brain and Liver Tissues Enzyme Activity in Balb/C Mice. Acta Veterinaria Brno, 71, 309-312. http://dx.doi.org/10.2754/avb200271030309

[50] Kennedy, G.C. (1969) Interactions between Feeding Behavior and Hormones during Growth. Annals of the New York Academy of Sciences, 157, 1049-1061.

[51] Martínez, A.G., López-Espinoza, A. and Martínez, H. (2006) Efectos de modificar el contenido energético del agua sobre el peso corporal, consumo de agua, alimento y calorías en ratas. Universitas Psicológica, 5, 361-370.

[52] Valenstein, E.S., Kalolewski, J.W. and Cox, V.C. (1967) Sex Differences in Taste Preference for Glucose and Saccharin Solutions. Science, 19, 942-943. http://dx.doi.org/10.1126/science.156.3777.942

[53] López-Espinoza, A. (2005) Son las dietas una "causa" del sobrepeso? Un análisis contrafáctico. Universitas Psychologica, 4, 23-29. 